\title{
Ex vivo distribution of gold nanoparticles in choroidal melanoma [Corrigendum]
}

Kanavi MR, Asadi S, Ahmadieh H. Ex vivo distribution of gold nanoparticles in choroidal melanoma. International Journal of Nanomedicine. 2017;12:8527-8529.

Affiliation 1 should have been presented as:

Ocular Tissue Engineering Research Center, Shahid Beheshti University of Medical Sciences, Tehran, Iran

\section{Publish your work in this journal}

The International Journal of Nanomedicine is an international, peerreviewed journal focusing on the application of nanotechnology in diagnostics, therapeutics, and drug delivery systems throughout the biomedical field. This journal is indexed on PubMed Central, MedLine, CAS, SciSearch $\AA$, Current Contents $₫ /$ Clinical Medicine,

\section{Dovepress}

Journal Citation Reports/Science Edition, EMBase, Scopus and the Elsevier Bibliographic databases. The manuscript management system is completely online and includes a very quick and fair peer-review system, which is all easy to use. Visit http://www.dovepress.com/ testimonials.php to read real quotes from published authors. 